\title{
Dirty money as legal fees in Namibia and Zimbabwe: are lawyers laundering proceeds of crime?
}

\author{
Jorum Duri \\ Department of Criminal Justice and Procedure, University of the Western Cape, \\ Cape Town, South Africa
}

\begin{abstract}
Purpose - The purpose of this paper is to explore the contentious issue whether lawyers become launderers when they accept dirty money as legal fees. Lawyers represent criminal defendants who may wish to pay for their legal fees with proceeds of their criminal activities. The paper analyses the legal position of Namibia and Zimbabwe on such tainted fees and proceeds to compare with the different position taken by the United States.

Design/methodology/approach - The paper adopts a desk research methodology with reliance on various sources such as statutory laws, case laws, books, journal articles and the internet. Its scope is limited to issue and content analysis relating to the use of dirty money as legal fees.

Findings - The paper shows that lawyers become launderers when they accept dirty money as legal fees with knowledge or suspicion of its origins. It concludes that the prohibition of dirty money as legal fees is important in the fight against economic crime in Namibia and Zimbabwe. Even though it is decriminalised in the USA, the continuous prosecution of lawyers for tainted fees shows that state authorities are aware of the dangers of tainted legal fees.

Originality/value - This paper adds to the few available literature on dirty money and legal fees. It provides sound reasons why prohibition of tainted attorneys' fees adds muscle to the fight against economic crime. No prior literature is available on tainted legal fees in Namibia and Zimbabwe specifically.
\end{abstract}

Keywords Attorneys, Dirty money, Legal fees, Lawyers, Launderers, Proceeds of crime, Namibia, Zimbabwe, Money laundering

Paper type Research paper

\section{Introduction}

Lawyers usually offer legal services to persons facing criminal charges of corruption, fraud, tax crimes, drug-related crimes or money laundering. Most persons implicated in such crimes have the financial muscle to hire the best legal minds in the country. Lawyers have a right to be paid for their services; but unfortunately, they may find themselves being offered dirty money as legal fees (Hamman and Koen, 2017). In a simple money laundering case, a criminal successfully cleans proceeds of crime by using it for any legitimate purposes. Also, it is a criminal offence for any person to accept such dirty money with knowledge or suspicion of its origins. However, such position is not simple with regards to the use of tainted funds as legal fees. On the one hand, criminalisation of attorneys' fee raises serious constitutional problems such as the right of the accused to legal representation and fair trial and the lawyers' right to practice their profession. On the other hand, a key concept in fighting financial crime is to deny criminals of any use or enjoyment of their dirty money. Lawyers are regarded as professional enablers of financial crime (Levi, 2015; Benson, 2016; Tax Justice Network, 2017). Their involvement with proceeds of crime requires a close scrutiny. There is a real risk of contamination of the entire financial system once dirty
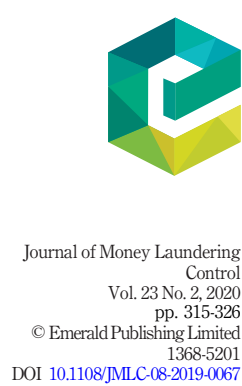
JMLC 23,2

\section{6}

money is allowed to get into the lawyer's account, either as payment of legal fees or for any other business.

Thus, a question is asked: are lawyers launderers for accepting dirty money as legal fees? This paper tackles the question by examining the legal position of Namibia and Zimbabwe on tainted legal fees. It will then compare with the US' position which legalises tainted fees and concludes by taking a stance on the issue.

\section{Dirty money as legal fees}

It is common for accused persons to hire best lawyers as their defense counsel and to wish to pay them with proceeds of their criminal activities. Corrupt persons may use their embezzled funds, drug dealers may use the profits from their cartels and corporations may use the proceeds from tax crimes. At its basic level, money laundering involves any transaction or agreement which uses proceeds of a crime in an attempt to disguise its illegal origin. Several international treaties have criminalised the acceptance, possession and use of dirty money, with knowledge of its origins. For instance, Article 3(1)(c)(i) of the United Nations Convention Against Illicit Traffic in Narcotic Drugs and Psychotropic Substances of 1988 criminalises the "acquisition, possession or use of property" with knowledge at the time of receipt that it was derived from a drug-related offence or from an act of participation in such offence or offences. Likewise, Article 23(2)(b)(i) of the United Nations Convention against Corruption of 2003 criminalises such acquisition, possession or use of a property with knowledge at the time of receipt that it constitutes proceeds of corruption. A similar offence is contained in Article 6(1)(b)(i) of the United Nations Convention against organised crime of 2004 in relation to proceeds of organised crime. The above treaties show a consensus at international level that no one should knowingly accept proceeds of crime and that includes for payment of legal services. By accepting dirty money as legal fees, a legal practitioner becomes involved in laundering proceeds of crime. Lawyers risk being prosecuted for their involvement in such money laundering activities (Bell, 2003).

A number of reasons can be put forward to prohibit lawyers from accepting tainted funds as legal fees. First, a key aspect in the fight against financial crime is denying offenders the opportunity to use and enjoy the proceeds of their criminal activities. By permitting use of dirty money to pay legal expenses, authorities will be allowing criminals such use and enjoyment of the proceeds of crime. Also, the use of tainted fees gives an unfair advantage to criminals who will hire the best legal minds in the country to escape liability against state prosecution with limited resources. From a moral point of view, it is unethical for attorneys to accept tainted fees based on the ground that lawyers should not knowingly "clean" the ill-gotten gains of their clients. This means that such individuals should rely on court-appointed lawyers for their legal defence if they cannot afford to pay legal expenses from clean sources (Orentlicher, 1999). Moreover, allowing tainted fees may result in defence lawyers becoming willing participants in cleaning of dirty money. Dishonest lawyers may take this opportunity to work with criminals to launder more proceeds of crime. For example, the lawyer may inflate legal fees to maximise dirty money which can be paid as legal fees. Once such money has successfully been deposited into the account of the practitioner as legal fees without raising any questions, it will come out clean.

By their professional nature, lawyers are susceptible to money laundering risks from clients. Regulators are asking lawyers to help in combating economic crime by requiring them to be vigilant when dealing with clients and to report any suspicious transactions (Goredema, 2018). The Financial Action Task Force on Money Laundering (FATF) has set out obligations for lawyers to assess risk of money laundering by their clients and a duty to report suspicious transactions in terms of its Recommendations 22 and 23 (FATF, 2012). In terms of 
Recommendation 23, lawyers have anti-money laundering obligations, including reporting of all suspicious transactions to the relevant financial intelligence unit. The interpretive note to Recommendation 23 provides that lawyers should not be required to report suspicious transactions which information was obtained in circumstances subject to circumstances where they are subject to professional secrecy or legal professional privilege. It goes on to state that:

It is for each country to determine the matters that would fall under legal professional privilege or professional secrecy. This would normally cover information lawyers, notaries or other independent legal professionals receive from or obtain through one of their clients: (a) in the course of ascertaining the legal position of their client, or (b) in performing their task of defending or representing that client in, or concerning judicial, administrative, arbitration or mediation proceedings (FATF, 2012, p. 83).

If a country decides to adopt the above approach, then lawyers will not have any obligation to report suspicion of dirty money by a client. The fact that the lawyer cannot report the dirty money by the client to relevant authorities does not mean he or she should accept tainted fees. The attorney-client privilege protects confidential communications for the purposes of obtaining legal advice, and it should not be used as a shield by lawyers to acquire proceeds of crime.

On the contrary, there are several challenges attached to criminalisation of tainted attorneys' fees. Lawyers may become reluctant to represent defendants whose alleged criminal conduct could taint the money used in payment of legal fees (Brickey, 1988). Lawyers may start categorising some defendants as "untouchables" due to their consistent link to economic crime and the possibility of their prosecution for accepting the tainted fees. The fear of possible prosecution "creates a conflict of interest, pitting the defence attorney's best interests against his client's" (Griffini, 2016, p. 184). An attorney who is under threat of prosecution for accepting legal expenses will be compelled to select between:

Limiting the investigation in order not to discover any information which may be used against him in a subsequent money laundering prosecution, and inquiring fully into the client's case in order to prepare and present competent legal advice (Weinsten, 1988, p. 385).

Also, criminalisation of legal fees may give ammunition to the prosecutor to "corner" lawyers into dropping from the case or for reaching a plea bargain with the accused. Such a position gives overzealous prosecutors the ammunition to go after the defendant's attorneys (Hamman and Koen, 2017). The prosecution may abuse and manipulate the position on tainted fees until the prosecution approves or agrees with the defendant's choice of counsel (Weinsten, 1988). This violates the constitutional right of the defendant to legal representation of his or her choice. In addition, if legal fees are subject to forfeiture by the government, then accused persons would be restrained in their ability to retain legal representation, thereby compromising their right to legal counsel and undermining the fairness of the criminal justice system (Orentlicher, 1999). Also, lawyers prosecuted for accepting such tainted fees may be forced to violate their attorney-client privilege to prove their lack of knowledge on such dirty money (Brickey, 1988). Thus, the criminalisation of tainted legal fees has the potential of turning a case which the lawyer is representing to a money laundering case against the lawyer.

Hence, the payment of legal fees with dirty money is a contentious issue. Countries have adopted different approaches to the issue. The paper shall proceed to look at the legal position in Namibia and Zimbabwe.

\subsection{Namibia}

2.1.1 Prevention of Organised Crime Act 29 of 2004. The Prevention of Organised Crime Act $(\mathrm{POCA})$ is the primary legislation which seeks to combat organised crime and money 
laundering in Namibia. Section 2 of POCA criminalises the receipt or retention of proceeds of racketeering by a person who knows or ought reasonably to have known of such origins, and using or investing any part of such proceeds, directly or indirectly, to acquire any interest in, or the establishment or operation or activities of, any enterprise. The key issue in the section is what constitutes an enterprise. Section 1 of POCA defines an enterprise as

Any individual, partnership, corporation, association, or other juristic person or legal entity, and any union or group of individuals associated in fact, although not a juristic person or legal entity.

Thus, any practitioner in an individual firm, a partnership or law firm, is included in the definition. This means that any lawyer in Namibia who accepts dirty proceeds of racketeering knowingly or ought to know, and uses or invests the tainted fees in the operations of the law business, may be charged with a money laundering offence.

Section 4 of POCA, which is the chief section on criminalisation of money laundering, states that:

Any person who knows or ought reasonably to have known that property is or forms part of proceeds of unlawful activities:

(1) enters into any agreement or engages in any arrangement or transaction with anyone in connection with that property, whether that agreement, arrangement or transaction is legally enforceable or not; or

(2) performs any other act in connection with that property, whether it is performed independently or in concert with any other person, and that agreement, arrangement, transaction or act has or is likely to have the effect:

- of concealing or disguising the nature, origin, source, location, disposition or movement of the property or its ownership, or any interest which anyone may have in respect of that property; or

- of enabling or assisting any person who has committed or commits an offence, whether in Namibia or elsewhere:

- to avoid prosecution;

- to remove or diminish any property acquired directly; or indirectly, as a result of the commission of an offence.

Hence, any agreement, arrangement or transaction involving dirty money, though legally enforceable, is criminalised. This means that even though a lawyer may have a right to legal fees for services rendered, it is illegal to accept dirty money. Thus, if a lawyer is aware or suspects that the client's money comes from an illicit source, then lawyer cannot accept the money without committing a crime. Also, it is a criminal offence to perform any acts relating to proceeds of crime which has or likely have an effect of hiding any trace of the dirty proceeds, or which will likely help an offender to escape justice, or to remove or diminish any property related to a criminal offence. Commenting on a similar position in South African law, Hamman and Koen (2017, p. 109) argue that:

The range of conduct which may constitute money laundering is extensive. It goes beyond transactions pertaining to criminal proceeds to encompass conduct relating to obstruction of justice as regards both a criminal and the proceeds of his crime. The POCA definition, it seems, seeks to include a comprehensive catalogue of conduct involving proceeds of unlawful activities. To this end it constructs a two legged offence which traverses both core and cognate conduct associated with money laundering. The applicability of the designated categories of conduct to the attorney-client relationship needs no justification. 
Section 4 ensures that no person should be allowed to get involved with dirty money knowingly or when he/she ought to have known of its unlawful origins, no matter the purpose of the transaction or arrangement, and escape liability. In other words, whoever gets in touch with dirty money has dirty hands.

Section 5 of POCA stipulates that any person commits the crime of money laundering if he or she knows or ought reasonably to have known that another person has acquired proceeds of unlawful activities and gets into any agreement to help any person to retain, control or use such proceeds. This provision covers typical attorney-client cases where attorneys have knowledge or reasonable suspicions that they client has brought to them dirty money, but still proceed to use that money further the interests of the client, for example, where a lawyer with knowledge of the proceeds of crime pays another law firm for the criminal defence of the client or any other person. In such a case, the attorney will be held criminally liable for money laundering. Section 6 of POCA criminalises the receipt, possession and use of any property by any person who knows or ought to reasonable know that it is a proceed of a crime committed by another person. Again, this section applies when a lawyer accepts tainted fees with knowledge or when he/she ought to have known that it is dirty money.

On the required mental element, POCA makes it clear that the lawyer should have knowledge or ought to reasonably have known of the origins of the money. Section 1 provides that:

(1) for purposes of this Act a person has knowledge of a fact if:

- the person has actual knowledge of that fact; or

- the court is satisfied that:

- the person believes that there is a reasonable possibility of the existence of that fact; and

- he or she fails to obtain information to confirm the existence of that fact.

(2) for the purposes of this Act, a person ought reasonably to have known or suspected a fact if the conclusions that he or she ought to have reached are those which would have been reached by a reasonably diligent and vigilant person having both:

- the general knowledge, skill, training and experience that may reasonably be expected of a person in his or her position; and

- the general knowledge, skill, training and experience that he or she in fact has.

This entails that the mental element for a lawyer charged with accepting tainted fees can be based on either dolus or culpa. In other words, a lawyer with direct knowledge of the dirty money (dolus directus) or who believed there was possibility of dirty money but failed to confirm that fact (dolus eventualis) meets the mental element of the commit the crime. Alternatively, the mental element can be inferred from negligence or failure by the lawyer to live up to the standards of a reasonable lawyer in a similar situation who would have reached the conclusion or suspected that the legal fees were proceeds of crime.

From the above provisions, it is clear that it is a criminal offence for lawyers to accept dirty money as legal fees in Namibia. There are no provisions in POCA indicating that a lawyer will not be prosecuted for being paid with dirty money nor it payment of legal fees pointed as a defence in Section 10. However, no attorney has been charged under the POCA for accepting dirty money legal fees.

Interestingly, the same law allows payment of legal expenses from assets restrained or confiscated as proceeds of crime. Article 26(1) provides that the High Court may grant an order to allow payment of reasonable legal fees for a person whose property has been 
JMLC 23,2

restrained as proceeds of the crime in question. To grant the order, the court should be satisfied that the person or any other person whom he or she is legally liable to support or maintain, have made a sworn statement on their full interests in the property and a list of all their assets and liabilities and that they cannot meet the legal expenses out of unrestrained assets. The same conditions apply in Section 57(1) which empowers the High Court to make an order allowing payment of reasonable legal expenses for a person whose property is subject to a preservation of property order. This creates quite a controversial position on dirty money as legal fees. On one side, lawyers can be prosecuted for money laundering if they accept tainted funds from clients. On the other side, the same lawyers may accept the same dirty money as legal fees, with permission from the court. On similar controversial provisions in South Africa, it has been argued that the correct position of the law is that "lawyers cannot accept dirty money as legal fees unless authorised to do so by the court dealing with recovery proceedings relating to the dirty money" (Hamman and Koen, 2017, p. 116). In other words, the court can "authorise" cleaning of dirty money for the same purposes criminalised by law.

2.1.2 Financial Intelligence Act 13 of 2012. The Financial Intelligence Act (FIA) established the Financial Intelligence Centre in Namibia. Section 1(1) of FIA defines money laundering as the act of a person who-

(1) engages, directly or indirectly, in a transaction that involves proceeds of any unlawful activity;

(2) acquires, possesses or uses or removes from or brings into Namibia proceeds of any unlawful activity; or

(3) conceals, disguises or impedes the establishment of the true nature, origin, location, movement, disposition, title of, rights with respect to, or ownership of, proceeds of any unlawful activity; where -

- as may be inferred from objective factual circumstances, the person knows or has reason to believe, that the property is proceeds from any unlawful activity; or

- in respect of the conduct of a person, the person without reasonable excuse fails to take reasonable steps to ascertain whether or not the property is proceeds from any unlawful activity; and

(4) any activity which constitutes an offence as defined in Sections 4, 5 or 6 of the Prevention of Organised Crime Act.

This definition makes it clear that lawyers can be held criminally liable for money laundering under FIA if they accept dirty money as legal fees. The specific reference to POCA denotes that a lawyer who acquires tainted fees in terms of POCA may also be held accountable for money laundering under FIA.

\subsection{Zimbabwe}

2.2.1 Money Laundering and Proceeds of Crime Act (Chapter 9:24). The Money Laundering and Proceeds of Crime Act (MLPCA) is the principal anti-money laundering legislation in Zimbabwe. Section 8(1)(b) of the MLPCA criminalises the conversion or transfer of property

For the purpose of concealing or disguising the illicit origin of such property, or of assisting any person who is involved in the commission of a serious offence to evade the legal consequences of his or her acts or omission. 
This provision has limited application to tainted fees. Lawyers can only be held accountable if they accepted dirty money and converted or transferred such money with intention to conceal or disguise its dirty origins. Also, representing a client with dirty money does not fall in the category of assistance in evasion of justice.

Section 8(3) of the MLPCA states that:

Any person who acquires, uses or possesses property knowing or suspecting at the time of receipt that such property is the proceeds of crime, commits an offence.

Hence, a lawyer who accepts tainted fees from a client with knowledge or suspicion of its illegal origin can be prosecuted for money laundering. A question can be asked whether a lawyer who becomes aware of such dirty money after the transaction can escape liability. What is more, can the lawyer report such transaction with the financial intelligence unit?

Section 30(1) requires reporting of all suspicious transactions to the financial intelligence unit. However, subsection 2 draws an exception for lawyers to report by stipulating that:

despite subsection (1), an estate agent or legal, accounting or corporate service professional is required to submit a report of a suspicious transaction in accordance with subsection (1) only when:

(1) they engage, on behalf of or for a client, in a financial transaction associated with an activity specified in relation to such professionals under Section 15(2)(a), (b) or (bl); and

(2) in the case of a legal practitioner, the relevant information upon which the suspicion is based was not received from or obtained on a client;

- in the course of ascertaining the legal position of his or her client; or

- in performing his or her task of defending or representing that client in,

or concerning judicial, administrative, arbitration or mediation proceedings, including advice on instituting or avoiding proceedings, whether such information is received or obtained before, during or after such proceedings.

This means that even though the lawyer becomes aware of dirty money from the client, he/she cannot report such information. This will be a clear violation of attorney-client privilege. In other words, the proof of knowledge or suspicion of money laundering cannot be derived from confidential communication between the client and the attorney. However, the fact that the attorney cannot report the suspicious transaction does not mean that the dirty money is allowed as legal fees.

On the required mental element, Section 5(5) provides that " $[\mathrm{k}]$ nowledge, suspicion, intent or purpose required as elements of an offence referred to in subsections (1), (2), (3) and (4) may be inferred from objective factual circumstances". This entails that similar to the Namibian position, the mental element for the money laundering offence can be based on direct or indirect intention. It can also be based on culpa that is taking an objective approach to the facts and determine whether a reasonable lawyer would have known or suspected that the fees received were proceeds of crime.

Similar to the Namibian position, the law allows payment for reasonable legal expenses from property subject to interdict for its connection to money laundering. Section 43(2)(b)(iii) provides that the High Court may grant an application by the Attorney General, a receiver, trustee or other relevant person to use the property or a specific part of the property subject to interdict for the payment of reasonable legal expenses for the person charged with a money laundering offence. According to Section 43(3), the court can make such an order only if it is satisfied that the person cannot pay the legal fees out of the property not subject to the 
interdict, and that it is in the best interest of justice to do so. Similar to Namibia, no legal practitioner has been prosecuted for accepting dirty money as legal fees in Zimbabwe.

\section{A comparative analysis: the legal position of the USA}

Anti-money laundering laws in both Namibia and Zimbabwe criminalise acceptance of dirty money as legal fees with knowledge or suspicion of its illicit origins. Such an approach is plausible as it ensures that no one is allowed to get involved with proceeds of crime, with knowledge or reasonable suspicion of its dirty origins. However, it is worth noting that the anti-money laundering laws in both countries permit the payment of legal fees from property which has been confiscated as proceeds of crime. In other words, a lawyer who renders services to a client facing prosecution for economic crimes may be paid with dirty money, by leave of court. Here, the court plays an important part as the only authority which can allow the "cleaning" of dirty money for payment of legal fees.

In comparison to Namibia and Zimbabwe, the USA has decriminalised the acceptance of dirty money as legal fees. In terms of Section 1957(a) of the Money Laundering Control Act of 1986, it is a criminal offence to knowingly engage or attempt to engage "in a monetary transaction in criminally derived property of a value greater than $\$ 10,000$ and is derived from specified unlawful activity”. Initially, Section 1957(f)(1) defined a monetary transaction as "the deposit, withdrawal, transfer or exchange, in or affecting interstate or foreign commerce, of funds or a monetary instrument. . .by, through, or to a financial institution (as defined in $§ 5312$ of title 31)”. Such broad definition meant that any financial transaction involving dirty money more than the prescribed amount was a criminal offense including such transactions by lawyers (Weinsten, 1988; Gaetke and Welling, 1992). The provision was criticised for its threat to the legal profession and its violation of the Sixth Amendment on the right to legal representation (Boylston, 1987; Rudovsky, 1988; Weinsten, 1988).

Due to the criticism on its threat to the legal profession and violation of constitutional rights, Section 1957(f)(1) was amended. It now reads:

[...] the term "monetary transaction" means the deposit, withdrawal, transfer, or exchange, in or affecting interstate or foreign commerce, of funds or a monetary instrument (as defined in §1956(c) (5) of this title) by, through, or to a financial institution (as defined in $§ 1956$ of this title), including any transaction that would be a financial transaction under \$1956(c)(4)(B) of this title, but such term does not include any transaction necessary to preserve a person's right to representation as guaranteed by the sixth amendment to the Constitution.

The amendment exonerates lawyers from criminal liability for any transaction that involves dirty money paid as legal fees to preserve the defendant's right to legal representation. In other words, payment of legal fees is not regarded as a financial transaction which warrants criminal prosecution for accepting dirty money regardless of when the attorney becomes aware of its dirty origins. It has been argued that even if the law was not amended, its intrusion on the Sixth Amendment would have compelled courts to dismiss prosecutions anyway (Gaetke and Welling, 1992).

The Department of Justice adopted internal guidelines to limit the use of Section 1957 against lawyers (US Department of Justice, 2018) The guidelines make it clear that:

The statutory exemption would allow criminal prosecution of defense attorneys who knowingly "receive and deposit" tainted funds either as part of a sham or fraudulent transaction, or as legal fees for representation of a client in any non-criminal matter.

Therefore, a defence attorney who abuses the provision to receive and deposit dirty money for sham or fraudulent purposes can be prosecuted for a money laundering offence. Furthermore, the acceptable of dirty money by lawyers in civil matter is not exempted by 
the statute. This is largely because the right to legal representation in civil matters is not constitutionally guaranteed. This was the case in Hullom v. Burrows, 266 F.2d 547, 548 (6th Cir.), cert. denied, 361 U.S. 919 (1959) where it was held that the Sixth Amendment right to counsel did not apply to civil matters. The guidelines go on to state that:

It would also permit prosecution of a defense attorney who "receives and deposits" tainted funds from a third-party payor as legal fees for representation of a client in a criminal case. Such thirdparty payments can hardly be said to be necessary to preserve the client's right to counsel in a criminal case because, in the absence of such payments, the client would still be free to retain private counsel with his own funds or to be represented by a public defender or court-appointed counsel if he could not afford to retain private counsel (US Department).

Such provision makes it clear that only proceeds of crime from the defendant can be accepted as dirty money. In the case of United States v. Blair 661 F.3d. 755 (4th Cir. 2011), an attorney was convicted of violating Section 1957 to use $\$ 20,000$ from drug proceeds to purchase two $\$ 10,000$ bank checks to retain attorneys for associates of his client. The Fourth Circuit held that his actions fell "far beyond the scope of the Sixth Amendment" as the right to legal representation was personal to the accused and did not extend the use someone else's money to hire legal representation. Thus, the payment of tainted fees by a third party was not exempted from criminal liability.

However, the Department of Justice is still keen on prosecuting lawyers who accept tainted fees knowing about its origins. The guidelines state that:

[T]he Department, as a matter of policy, will not prosecute attorneys under $§ 1957$ based upon the receipt of property constituting bona fide fees for the legitimate representation in a criminal matter, except if

(1) there is proof beyond a reasonable doubt that the attorney had actual knowledge of the illegal origin of the specific property received (prosecution is not permitted if the only proof of knowledge is evidence of willful blindness); and

(2) such evidence does not consist of (a) confidential communications made by the client preliminary to and with regard to undertaking representation in the criminal matter; or (b) confidential communications made during the course of representation in the criminal matter; or (c) other information obtained by the attorney during the course of the representation and in furtherance of the obligation to effectively represent the client.

The above provision depicts that an attorney can be prosecuted for accepting dirty money with actual knowledge of its origins provided that the state can prove the actual knowledge beyond any reasonable doubt without any evidence from the attorney-client communications.

The case of United States $v$ Velez F 3d 875 (11th Cir 2009) indicated that lawyers are still at risk of being prosecuted for accepting tainted fees. In this case, US attorney named Kuehne, was hired by a Miami-based criminal defence team of Fabio Ochoa, an accused Colombian drug leader, to review the source of funds to be used to pay Ochoa's legal defence fees in the USA. The review was aimed at ascertaining whether the defence team had received legal fees from criminal proceeds. Kuehne hired two professional to assist him with the investigation. He concluded that the several monetary transfers from Ochoa to him, as an intermediary, were not proceeds of dirty money. He then used the money to pay legal expenses to Ochoa's defence team, totalling around $\$ 5.3 \mathrm{mn}$. The state prosecuted Kuehne and his co-defendants based on the allegations that they supported their conclusion that the funds were untainted with false documents and statements, knowing that the funds were 
criminally derived and with intention to conceal their illegal source. In both court a quo and on appeal, the case was dismissed on the ground that monetary transactions made for the purpose of securing legal representation were exempt from criminal penalties under Section 1957(f)(1). The Eleventh Circuit (para. 12) found that, regardless of the attorney's actual knowledge, "the plain language of $§ 1957(f)(1)$ clearly exempts criminally derived proceeds used to secure legal representation to which an accused is entitled under the Sixth Amendment".

Hence, the USA allows dirty money as legal fees even when the attorney has knowledge or suspicion of the origins of such dirty money, unlike the legal position in Namibia and Zimbabwe. However, the above cases have shown that the authorities are still not comfortable with the use and enjoyment of dirty money for payment of legal fees.

\section{Taking a stance against tainted attorneys' fees}

The issue of dirty money as legal fees is still contentious. However, there is a need to take a stance against the use of dirty money for any legitimate or illegitimate purposes. The fight against economic crime commands that no person should be allowed to use and enjoy the proceeds of his or her criminal activity. Allowing a criminal offender to build a strong defence team with proceeds of crime defeats the effort by authorities to fight crime. In many instances, under-resourced state prosecutors stand no chance against strong defence team assembled using dirty money. In other words, the criminal will be able to use dirty money to seek bail applications, delay proceedings, gather and prepare evidence and to defend the case. A criminal defendant should not be given an undue advantage and should be put in the position he or she would have been prior to acquiring proceeds of crime. This means that attorneys' fees should be paid from legitimate sources. Allowing tainted fees for attorneys creates the impression that crime does not pay, expect for legal fees (Unger, 2007). Such impression erodes the authority of authorities to enforce anti-money laundering laws. The public may lose confidence in a government which allows criminals to benefit from crime.

The US position is that criminalisation of legal fees violates the constitutional right to legal representation. Article 12(1)(e) of the Constitution of Namibia and an Article 70(1)(d) of the Constitution of Zimbabwe guarantee such right to legal representation. However, the right to legal representation is not an absolute right, it is subject to limitation. It is in the best interest of the society to fight crime by denying criminals the fruits of their crime. Therefore, the right is limited justifiably if the chosen legal representative is paid by such proceeds of crime. Criminalisation of tainted fees does not restrict the person from choosing a lawyer but restricts the use of dirty money to pay such a lawyer. The defendant is free to choose any legal practitioner of his or her choice, provided he can afford to the lawyer with clean money. If the defendant cannot afford legal representation on own legitimate expense, then he or she is guaranteed the right to be represented by a public defender paid by the state.

Allowing dirty money as legal fees opens doors for money launderers to access lawyers with little repercussions. It may trigger attorneys to become willing participants in the cleaning of dirty money through legal fees. As argued earlier, the fact that the practitioner cannot disclose privileged information shared by the client regarding dirty money is not a ground to accept proceeds of the crime as legal fees. The continuous prosecution of lawyer for accepting dirty fees in the USA, despite its decriminalisation, shows that authorities are aware of the dangers of allowing lawyers to accept such tainted fees with full knowledge of its illegal sources. Once lawyers have accepted fainted fees and continues a business relationship with the client, there is a real risk that lawyers may become active participants, knowingly or ignorantly, in the cleaning of dirty money. 


\section{Conclusion}

Lawyers become launderers when they accept dirty money as legal fees with knowledge or suspicion of its origins. Though a contentious matter, criminalisation of tainted fees adds muscle to the fight against economic crime. It makes it clear that no person should come out with clean hands after getting involved with dirty money. This position is made clear in both Namibia and Zimbabwe. The exception is when a court makes a ruling which guarantees that a lawyer is paid for service rendered in situations where the defendant cannot afford legal fees from legitimate sources. Comparatively, the USA has exempted lawyers from prosecution for accepting tainted fees; but interestingly, lawyers are still being prosecuted. The anti-money laundering legislations pertaining to tainted fees in Namibia and Zimbabwe are still to be tested in court to determine their constitutionality. However, it is likely to pass the constitutional test as the criminalisation does not limit the right of the defendant to choose legal representation but restricts the defendant from using dirty money to pay for the legal fees. Lawyers are professional enablers of financial crime and their wilful involvement with proceeds of crimes should not go unchecked. There is a real risk of contamination of the entire financial system once dirty money is allowed to get into the lawyer's account, either as payment of legal fees or for any other business. All in all, it should be made clear that crime does not pay, even for attorneys' fees.

\section{References}

Bell, R.E. (2003), "The prosecution of lawyers for money laundering offences", Journal of Money Laundering Control, Vol. 6 No. 1, pp. 17-26.

Benson, K. (2016), "The facilitation of money laundering by legal and financial professionals: roles, relationships and response", Unpublished Doctor of Philosophy thesis, University of Manchester.

Boylston, L.D. (1987), "Attorneys' fees and the money laundering control act of 1986: further erosion of criminal defense advocacy”, Georgia Law Review, Vol. 21 No. 4, pp. 929-965.

Brickey, K.F. (1988), "Tainted assets and the right to counsel - the money laundering conundrum", Washington University Law Review, Vol. 66 No. 1, pp. 47-61.

FATF (2012), "International standards on combating money laundering and the financing of terrorism and proliferation: the FATF recommendations", available at: www.fatf-gafi.org/publications/ fatfrecommendations/documents/fatf-recommendations.html (accessed 20 March 2019).

Gaetke, E.R. and Welling, S.N. (1992), "Money laundering and lawyers", Syracuse Law Review, Vol. 43, pp. 1165-1245.

Griffini, P.J. (2016), "Of laundering and legal fees: the implications of United States v Blair for criminal defense attorneys who accept potentially tainted funds", University of Pennsylvania Law Review Online, Vol. 164, pp. 179-205.

Goredema, C. (2018), "Not above the law? the role of lawyers in combating money laundering and illicit asset flows", The Global Initiative against Transnational Organised Crime, available at: https:// globalinitiative.net/lawyers_report/ (accessed 19 March 2019).

Hamman, A. and Koen, R. (2017), "Pecunia non olet: dirty money as legal fees", Journal of antiCorruption Law, Vol. 1 No. 1, pp. 107-131.

Levi, M. (2015), "Money for crime and money from crime: financing crime and laundering crime proceeds", European Journal on Criminal Policy and Research, Vol. 21 No. 2, pp. 275-297.

Orentlicher, D. (1999), "Representing defendants on charges of economic crime: unethical when done for a fee", Emory Law Journal, Vol. 48, pp. 1339-1376.

Rudovsky, D. (1988), "The right to counsel under attack", University of Pennsylvania Law Review, Vol. 136 No. 6, pp. 1965-1973. 
JMLC 23,2

Tax Justice Network (2017), "The professionals: dealing with the enablers of tax avoidance and financial crime", available at: www.taxjustice.net/wp-content/uploads/2017/11/The-Enablers-ofTax-Avoidance-TJN-Briefing.pdf (accessed 27 March 2019).

Unger, B. (2007), "Implementing money laundering", in Masciandaro, D., Takats, E. and Unger, B. (Eds), Blank Finance: The Economics of Money Laundering, Edward Elgar Publishing, Cheltenham, pp. 103-147.

US Department of Justice (2018), "Justice manual: criminal, money laundering", available at: www. justice.gov/jm/jm-9-105000-money-laundering (accessed 30 March 2019).

Weinsten, A.K. (1988), "Prosecuting attorneys for money laundering: a new and questionable weapon in the war on crime", Law and Contemporary Problems, Vol. 50 No. 1, pp. 369-386.

\section{Corresponding author}

Jorum Duri can be contacted at: durijorum@gmail.com

For instructions on how to order reprints of this article, please visit our website: www.emeraldgrouppublishing.com/licensing/reprints.htm

Or contact us for further details: permissions@emeraldinsight.com 